\title{
The Influential Factors on the Service Recovery Implementation: Taking Banking Industry as an Example
}

\author{
Di Fan ${ }^{1, a}$ \\ ${ }^{1}$ Faculty of Accounting, Tianfu College of Southwestern University of Finance and Economics, \\ Mianyang, Sichuan Province, China \\ amsfandi@163.com
}

Keywords: Service Recovery, Banking Companies, Company's Perspective.

\begin{abstract}
Service recovery is viewed as an important process to strengthen customer relationship, retain the loyalty and stabilize the profit of company. As previous studies mentioned mainly focus on how to satisfy the customer and create customer loyalty through service recovery strategies. It is assumed that the company will do whatever it takes to solve customers' problems in order to retain them. This study is based on banking industry as an example and analyzes the service recovery from the companies' perspective. Finally, the empirical study shows that the values of customers, the core values of company and the employees' self-benefit consideration will be the main factors which will influent the implementation on the service recovery in banking companies.
\end{abstract}

\section{Introduction}

Service recovery is viewed as an opportunity for companies to strengthen customer relationships, increase customer trust and satisfaction, and reassure customers of their decision to enter into the relationship (DeWitt et al., 2007). According to Hart et al. (1990), the cost to replace a customer is five times more than to retain one. When companies fail to deliver, it is crucial for them to identify ways to best manage the service failure and effectively implement service recovery.Industry such as banking has become increasingly aware of the importance of quality improvement in satisfying customers' demands and expectations, and in gaining the trust and loyalty. (Leal \& Pereira, 2003; Lin et al, 2007). However, regardless of the type of interaction with customers, service failures via technical and human errors are inevitable, and an effective service recovery framework is needed in order to enhance customer satisfaction despite the presence of service failures.Many studies have been conducted on how service recovery efforts impact on customer satisfaction and the organization management, or how to increase customer loyalty through effective service recovery. In most of these aforementioned studies, the focus is usually from consumer's point of view (Ganesan \& Hess, 1997; Garbarino, 1999).

In a study of service failures and recovery in retail banking, Lewis and Spyrakopoulos (2001) identified various types of service failures and banking recovery strategies through interviews with bank customers. The findings showed that customers' perceptions of magnitude of service failures depended on customers' previous experiences. The study found that different recovery strategies were more effective for particular service complaints and problems, and that some problems were more difficult than others to deal with. Michel (2004) studied service failures of a bank and their effect on customer satisfaction and recommendation. The author proposed a model of service failure pyramid in order to deal with service recovery in a bank. However, if service failures are unacceptable or absolutely unacceptable, the costs of such failures increase significantly - customers are more likely to switch to other banks because of high dissatisfaction coupled with the fact that the reputation of the bank is affected by negative word-of-mouth. The previous studies assumed that the company will do whatever it takes to solve customers'problems in order to retain them. However, this study is trying to analyze the service recovery from the company's perspective. 


\section{Methodology}

The qualitative research was used to analyze the service recovery from the company's side. Empirical data was collected in the form of electronic mails which replied by banking companies. The content of e-mails includes complains and suggestions based on customers service experiences, especially the bad ones. The survey process went on for one week. We select 15 customers which consumption in certain banks frequently, then totally of 15 e-mails to 15 different banks which located in different provinces in China (Such as Sichuan, Shan Dong, Hu Nan and so on) and one bank located in Thailand. Finally, 9 replies were received, of which 6 were chosen for analysis. After analyzing the service failures and problems, the recommendations and suggestions were given to each individual bank separately.

As complaints are the most direct way that reflects the bad service experience. Refer to Michel (2004), we used the scale as mentioned in the paper and developed it based on the pre-interviews with the staffs in the banking companies. In the tables below, the complaints were defined seven items which will be used as design the questions in the survey e-mails. The seven items are: Long and/or unorganized queues, Limited network of facilities, Understaffed, Too much bureaucracy, Functional/technical failures of service, Favoritism or discrimination experienced, Unfriendly staff.

\section{Findings}

We received three e-mail replies from six banks which we personally encountered a service failure with - CITIC Bank of China, Industrial and Commercial Bank of China(ICBC), Agriculture Bank of China (ABC), China Construction Bank(CCB) and Bangkok Bank of Thailand. From their responses, the issues influencing each bank's implementation of service recovery emerged clearly through each company's position.

Factors Influence on Implementation Service Recovery. Based on the replies from companies, the factors which will influence the implementation on service can be explained as four factors: The cost, Employees' self - benefit consideration, core value of company and value of customers.

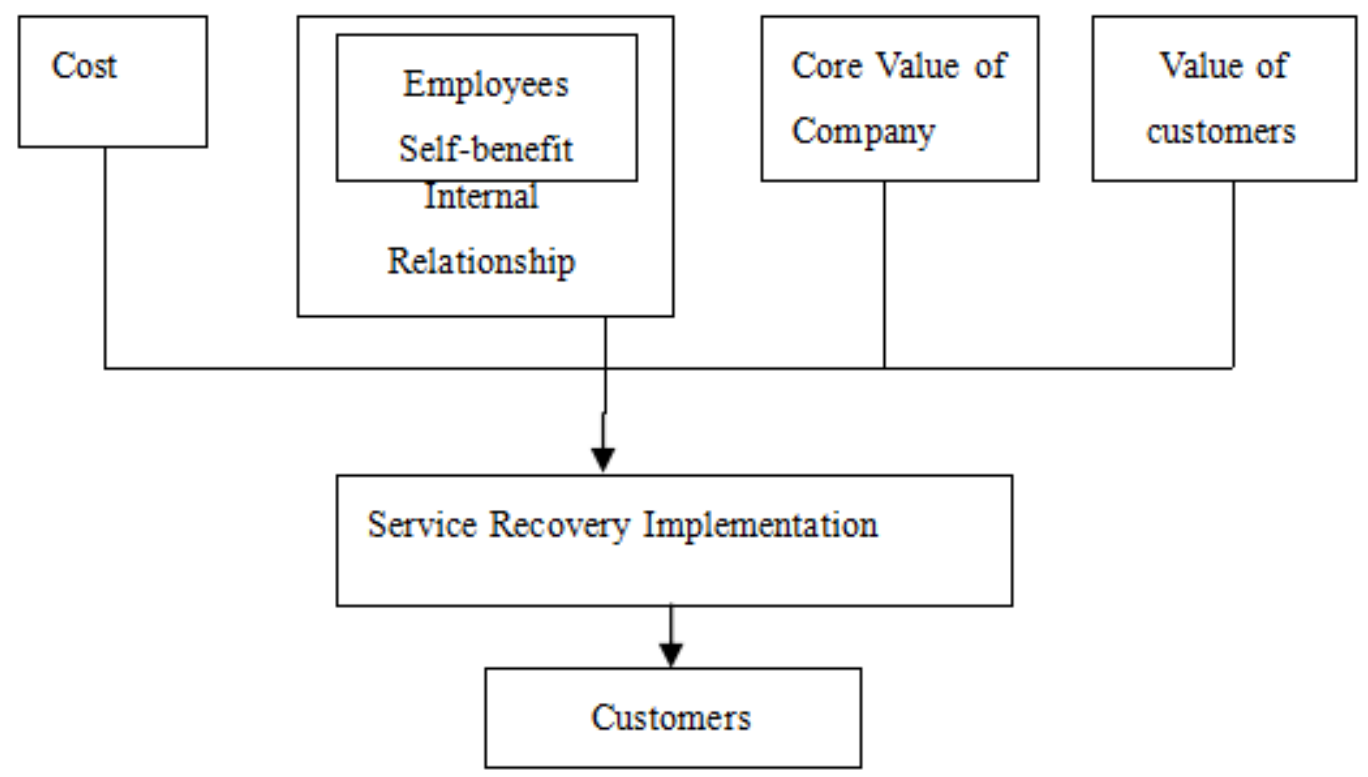

Fig. 1. The issues influencing the implementation of service recovery in the banking industry

Values of Customers. Values of customers will decide the investment of company in a relationship, inclusive of service recovery. (Soren Hougaard et. al, 2002)The level of profitability from customers will provide an indication to the company on whether or not it should invest in a relationship (ibid). In the reply from $\mathrm{ABC}$, the manager of the service department mentioned that the final aim of the bank is the pursuit for maximum profit. He also pointed out that the low-income customers will not bring much profit to the bank, so the bank will not focus too much on this group, and even try to reduce the 
business from these low-income customers. Most commercial banks in China focus on attracting big clients who can then bring higher level of profitability.

Core Values of the Company. Servicerecovery implementation has to balance between the company's core values and the satisfaction of customers. From a company's point of view, its core value is treated as an intangible asset, principle or profit of the organization (Kapferer, 2004). In the reply from CITIC bank,"The service recovery is not implemented on one-way. On one side, bank will accept complaints from customers, in another side,employees should to (sic) obeying the core value and principles of bank during service recovery process." Bankshave its bottom line to satisfy all requirements from customers. To some extent, the'bottom line'limitsitscapabilities to fulfilcustomers' requests and implement service recovery in service failure.

Employees'Self-benefitConsideration. When employees receive complaints from customers, their first reaction is to calm the consumers(e.g. send gifts to comfort customers). Sending complaints up to senior managers or the relevant departments will be employees' last option. Complaints are commonly viewed as reflectors of self bad performance, which will directly or indirectly influence employees' benefit.

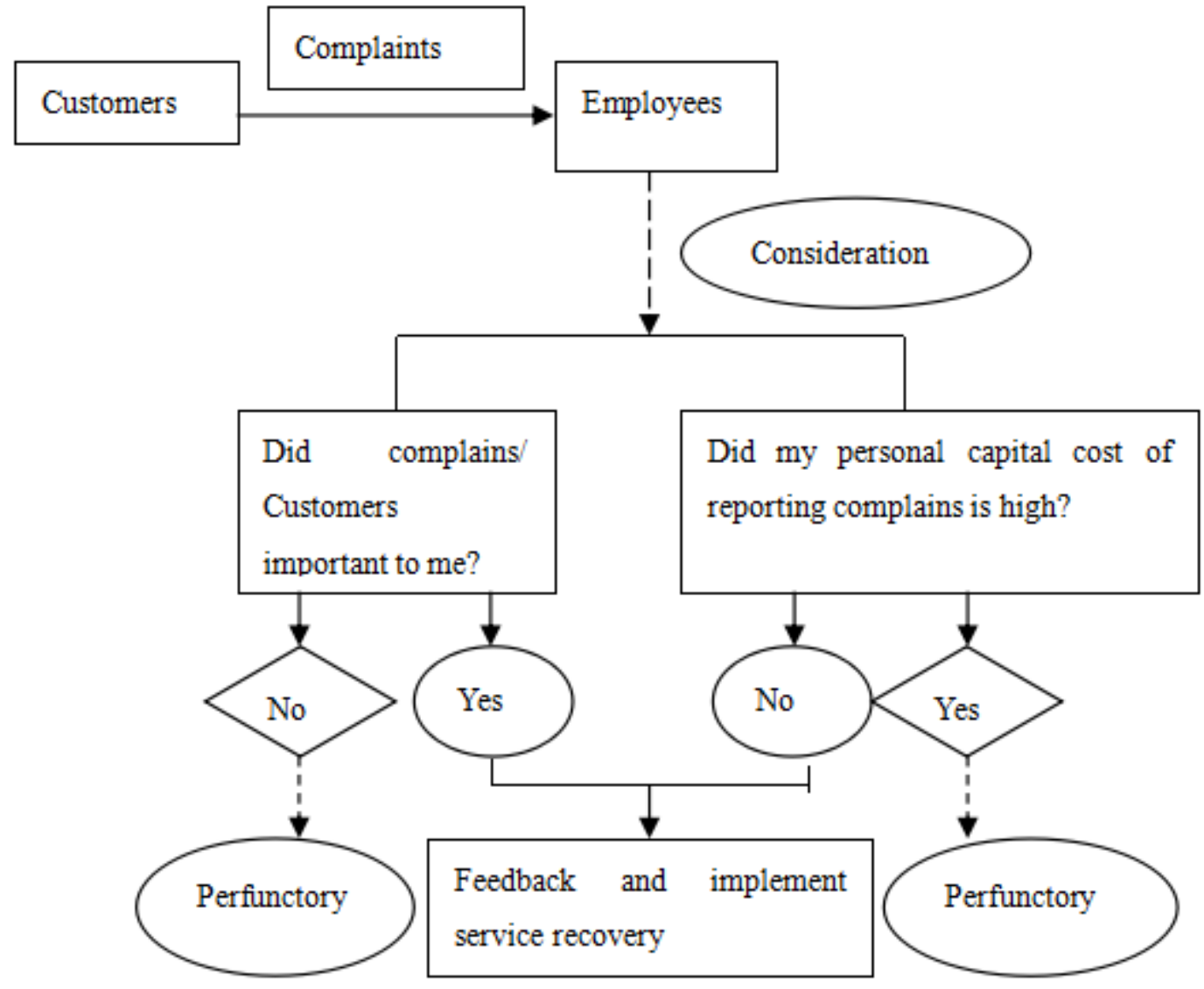

Fig. 2. The psychological process of consideration from employees

Empowerment. The company must empower employees certain authority andresponsibility to cope with customers' complain. (Heskett et al 1990). As mentioned above, employees' consideration about self-benefit reflect that they didn't have enough power to do service recovery. If organizations empower workers some authorities then the employees in front line will not be positioned in a passive situation in service recovery.

Cost on Service Recovery. The financial cost determine the quality of service recovery, for example, the cost of adding service facilities make companies react inefficiency on complains. Moreover, the relevant cost will occurs like 'chain reaction' as followed: 


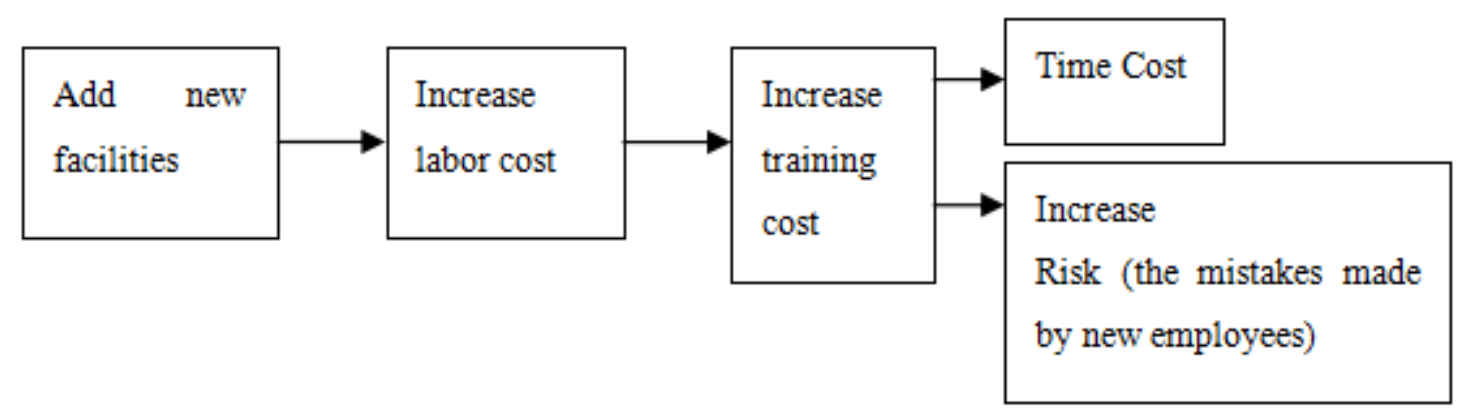

Fig.3. The increasedcost will bring new risk

\section{Suggestions for the Banking Industry}

Social Responsibility Can not Been Ignored. Some banks pursue maximize profit and ignore the service recovery on low-income customers. However, the duty and obligation which banks should obeyis serving customers without differential treatment. Money-oriented is important, but "word of mouth" will establish the social image for the banks. Moreover, the e-mail replies didn't clarify the definition on so-called "valuable customers". In our opinion, "valuable customers" is flexible and should cover all customer segments. e.g. low-income consumers is valuable group can bring "Economies of scale"affection and have potential to become big clients. Banks should have long-term vision on customers' development and benefit from social image.

The balance between customers' satisfaction and the cost. Companies known for excellent service will require the extra cost (James L. Heskett, 1990) which may conflict with the satisfaction of customers. We suggest that companies anticipatingneeds for recovery and do some preparation on these areas. Secondly, measuring the cost of lose a customer/ cost of service failure and the cost of preparation for an anticipate needs of service.

Empowering the front line employees. The organization must train all its employees especially front line staffs, who interact directly with customers, and then it must empower them. That is, the firm should give them the authority, responsibility, and incentives to recognize, care about, and attend to customer needs. Training can go a long way in developing the communications skills and creative thinking needed to deal with irritated customers, moreover, the effective training can change the self-standards of employees and decrease loss/risk for banks.

\section{References}

[1] Amy K. Smith, Ruth N. Bolton, Janet Wagner (1990), "A Model of CustomerSatisfaction with Service Encounters Involving Failure and Recovery." Journal of MarketingResearch, Vol. 36, No. 3, pp. 356-372

[2] Amy K. Smith, Ruth N. Bolton (1998), "An Experimental Investigation of ServiceFailure and Recovery: Paradox or Peril?" Journal of Service Research, 1 (1), 1998, 65-81.

[3] Berry, L. L. (1996). Retailers with a future. Marketing Management, 5, 38-46.

[4] Barbara R. Lewis and Pamela McCann, (2004), "Service failure and recovery:evidence from the hotel industry", International Journal of Contemporary Hospitality Management, Vol. 16, November 1, pp. 6-17

[5] C Fornell, B Wernerfelt (1987), Defensive marketing strategy by customer complaint management: a theoretical analysis, Journal of Marketing Research, Vol. 24, No. 4 (Nov., 1987), pp. 337-346

[6] Collie, T. A., Sparks, B., \& Bradley, G. (2000). Investing in interactional justice: a study of the fair process effect within a hospitality failure context. Journal of Hospitality and Tourism Research, 24(4), pp. 448 - 472 
[7] DeWitt, T., Nguyen, D.T., Marshall, R. (2007). Exploring Customer Loyalty Following Service Recovery: The Mediating Effects of Trust and Emotions. Journal of Service Research Publisher, Vol. 10, Iss. 3, pp. 269-281.

[8] Fu Min, Tao Changgao and Li Shaojun (2006), "Discussion on Stock shares reform", Economic Theory and Economic Management, Vol.1

[9] Ganesan, S., \& Hess, R. (1997). Dimensions and levels of trust: implications for commitment to a relationship. Marketing Letters, 8(4), 439-448.

[10] Garbarino, E., \& Johnson, M. (1999). The different roles of satisfaction, trust and commitment for relational and transactional consumers. Journal of Marketing, 63(2), 70-87

[11] Gummesson, E (2002) Total relationship marketing: Rethinking Marketing Management. Second edition. Elsevier, Oxford, USA.

[12] Hart, C.W.L., Heskett, J.L. and Sasser, W.E. (1990). The profitable art of service recovery. Harvard Business Review, Vol. 68 No. 4, pp. 148-56.

[13] Heskett, James L., Sasser,W.Earl and Hart,Christopher W.L.(1990), Service Breakthroughs.New York: The Free Press

[14] JN Kapferer (2004), "the new strategic brand management: creating and sustaining brand equity long term", Kogan Page Publishers

[15] Johnston, R., Fern, A. (1999), "Service recovery strategies for single and double deviation scenarios", Service Industries Journal, Vol. 19 No.2, pp.69-82.

[16] Michel, S. (2004), "Consequences of perceived acceptability of a bank's service failures", Journalof Financial Services Marketing, Vol. 8 No. 4, pp. 388-400. 